\title{
Congenital pseudoarthrosis of the limbs
}

INSERM

\section{Source}

INSERM. (1999). Orphanet: an online rare disease and orphan drug data base. Congenital pseudoarthrosis of the limbs. ORPHA:157808

Congenital pseudoarthrosis of the limbs is a rare, genetic, non-syndromic limb malformation characterized by delayed union or non-union of a long bone, resulting in formation of a false joint, with abnormal mobility and angulation at the pseudoarthrosis site, which manifests with progressive anterolateral forearm or leg bowing, limb shortening, and non-healing fractures. Typical histopathological findings include fibromatosis-like proliferation in the soft tissues with cystic or dysplastic lesions. Neurofibromatosis and osteofibrous dysplasia are frequently associated. 